\title{
Perspective Of Public Choise In Institution Political Economy
}

\author{
Munawar Noor \\ MS Lecturer Home Based Public Administration Magister Program, \\ Social and Politic Fakulty on 17 August 1945 University, Semarang, Indonesia
}

\begin{abstract}
The dichotomy between economics and politics has been so long that both are incapable of giving the same conclusions about the object being studied. Economics only examines the institutional aspects of the market without touching the non-market social institutions. The basis of market institutions to see the economic phenomenon while based on politics is very poor analytical framework. The perspective of public choice as a link that can provide a framework of analysis based on market phenomena. This allows the re-enactment of economic and political fields within a region. Analysis of the close relationship between economics and politics can be studied from the historical aspect, the collaboration between economics and politics, and the achievement of state goals, the cooperation among experts in each field, the analysis of national development, the condition of a country. Thus found a new phenomenon that connects the two that cannot be captured perfectly by both groups.
\end{abstract}

Keywords: Public Perspective, Economics, politics, public option

\section{INTRODUCTION}

The economic-political dichotomy in the history of its development is increasingly separated from one another. Each one is represented by the experts seeking reasoning and theory with different approaches that leads to a different new paradigm.

This fact of development shows that parts of the social sciences are moving away from one another as the focus of attention and the analytical framework become more specific. The social sciences with its various branches include the economics of fragmentation, making it difficult to find common ground despite the similarity of objects and subjects studied. Economics, for example, only examines the institutional aspects of the market with its various phenomenons so that it cannot touch the social institutions that are not the market.

Meanwhile political science and other social sciences are very poor analytical frameworks to look at economies that are marketed on market institutions. It is this dichotomy that allows the public choice to bridge between economics and politics that can analyze problems beyond the analytical framework that culminates in market phenomena. The theory of public choice can be used to study the behavior of political actors in the determination of effective public policy choices.The public choice is the electorate, political party politicians, bureaucrats and interest groups traditionally studied by many political experts.

\section{POLITICAL AND ECONOMICAL RELATION}

The relationship between economy and politics can be seen from various aspects that show the close relationship between economy and politics:

1. The historical aspect, the earlier thinkers thought that economics was a branch of political science that this led to economics being considered as a branch of political science. 
2. Collaboration between economics and political science, as the development of the era of economics is considered a branch of political science has stood alone or become independent.

3. Achieving the goals of a country, all countries must have a purpose to prosper the community and create conditions that support for the development and progress of the country.

4. Cooperation among experts in each field, in this case between economic scholars and political scholars can exchange knowledge or cooperate in achieving a particular purpose.

5. Analysis of national development, as time goes by economics becomes more developed, progress here and there, especially in the international economy.

6. The conditions of a country, the presence and the relationship between economics and politics are clearly visible in accordance ith the state or state of the state. For example, during the collapse of the New Order era in Indonesia, there was a monetary crisis that showed that politics greatly affect the economic condition of a country.

\section{PERSPECTIVE OF PUBLIC OPTIONS}

Buchanan (1989) explains that the concept of public choice is not a narrow theory but as a perspective. A public perspective is used in order to discuss and give meaning to the concept of public choice that can help analysts gain focus on this concept. The public choice is a political perspective born out of the development and application of the tools and methods of economics to the collective decision-making of various non-market phenomena.

In implementing a public choice perspective we do not have to make mistakes in highlighting and suggest that the element of power in political relations is extortion. In this case the public choice perspective on politics becomes analogous to the perspective of economic power on the market.

But there is a normative implication that needs to be derived from a public choice perspective on politics, the implication that in turn leads them to an approach to institutional reform. This implication creates a normative belief for the productivity of the electorate of choice economies to prefer such an order as to market transactions that it is possible to favor the decentralization of authority over political power.

\section{DEVELOPMENT OF PUBLIC CHOICE PERSPECTIVE}

Based on the separation occurring in the development of the social sciences (economics, social, politics), there is an attempt by a group of economists to go a step further to look at nonmarket institutions within the framework of economic well-being. This new theoretical framework seeks to see the phenomenon of government as an actor in the political and economic field or the individual's attitude in choosing his representatives in the parliament. In the 1980s political literature was filled with writings about rational choice or public choice.

Rational choice; the analogy of demand and supply of commodities according to classical economic law becomes the basis and framework of thinking of public choice in penetrating social and political field. Voters in a more democratic relationship can be regarded as consumers that should be provided by election-winning politicians / governments because of the support of the electorate.

Based on this analogy the government can be assumed as a supplier that provides public commodities for the community. 
The public choice focuses on the function of social choice or exploration of social welfare ownership. The analysis of public choice is directed at the problem of aggregation of the individual's freedom to maximize the social welfare function.

The basic description of the public-choice approach is the emphasis in assessing rational decisions by individual members of society, citizens and even rational decisions of government.

\section{CONCLUSION}

However, the choice of the public and the rational choice is criticized and considered a naive approach to taking into consideration individual action only on the side of individual rationality, thereby putting aside the institutional, cultural and political wealth of society.

The answer to the choice of public experts and the rational choice of criticism is that this approach is not intended to look at such things, because the approach is deductive. Hence the approach of public choice and rational choice cannot be justified solely by a deductive approach.

The rational choice approach is preferred for answering the question of the relation between economics and politics and economics which is still dark because they are growing apart from each other, not touching and moving in a mutual direction.

The framework of analysis of rational choice is not meant to answer all the problems but because the new way can surely synthesize a meeting between political science and economics. However, the latest approach to conservatism in economics and political science is to be solved by proposing a new approach of public choice and rational choice.

\section{Readings:}

Buchanan, James, 1989, Essay on Political Economy, Honolulu: University of Hawaii Press

Bustanul Arifin, Didik J Rashbini, Ekonomi Politikdan Kebijakan Publik, Indef, Fisip Universitas Indonesia, Jakarta, 2001

S. Leksono, Runtuhnya modal Sosial, Pasar Tradisional, CV Citra Malang, 2009 